\title{
THE IMPORTANCE OF THE AUDITED FINANCIAL STATEMENT IN ATTRACTING FOREIGN INVESTORS IN PRIVATE SECTOR IN KOSOVO
}

\author{
Leonora HALITI RUDHANI ${ }^{1}$, Hysen ISMAJLI ${ }^{2}$, Albulena MUSTAFA ${ }^{3}$ \\ ${ }^{1}$ University of Applied Sciences Ferizaj, Republic of Kosovo, \\ ${ }^{2,3}$ University of Prishtina, Republic of Kosovo, \\ Corresponding author e-mail: hysen_rismajli@yahoo.com
}

\begin{abstract}
Responding to globalization of the international business environment the companies need to draw and present reliable and comparable audited financial statements, and consequently there is a vital need to implement international financial reporting standards. Foreign investments in Kosovo as a new developing country are growing. The purpose of this paper is to consider the role of audited financial statements in encouraging foreign investment in the private sector in Kosovo. To examine this issue, we have analysed three determinant factors in presenting financial statements to the foreign investors: auditor's report, auditor reputation and relevance of auditor's findings. The results of this study indicate that these variables have a positive effect on promotion of foreign investment. These results also revealed that audited financial statements are very important for Kosovo companies in order to ensure an equal worldwide treatment.
\end{abstract}

Keywords: Audited financial statements, audit report, auditor reputation, foreign investments, findings.

\section{INTRODUCTION}

Along with globalization of the international business environment and entrance of new companies to the stock exchanges of many countries, a vital need to implement International Financial Reporting Standards (IFRS) has emerged.

One of the purposes of applying international standards for reporting and funding is to create similar, credible and transparent statements, which promote growth of capital and trade worldwide. Investors are interested in markets they understand and trust. According to international standards for reporting and financing, audited financial statements ensure reliability of data for foreign investors.

It is considered that audited financial statements and personal interviews are the most accurate sources of information that investors rely on (Berry \& Robertson, 2006).

Besides investors and analysts, other parties interested in qualitative information that may base their investment decisions include creditors, suppliers, customers, organizations, etc. They want to compare the data presented by the company with its competitors both in the same country and other countries of the 
world. To adjust to these global changes and to facilitate favourable decisions of foreign investors, Kosovo's government and business community moved quickly toward adoption of these standards, which are very important for the business climate. International corporations need not adopt specific standards to work in Kosovo if they apply IFRS at their headquarters. These are acceptable and applicable standards for both reporting and taxation (American Chamber of Commerce in Kosovo - the reasons to invest in Kosovo).

In some parts of the world, for instance, in the United States and Japan, private companies operate without any legal requirement to make financial statements public (Arruñada, 2010). In turn, in the countries of the European Union, private companies need to prepare financial statements and make them public. In 2011, the Parliament of the Republic of Kosovo adopted the Law on Accounting, Financial Reporting and Auditing, which regulates accounting and financial reporting of companies, competences and responsibilities of Kosovo's Council for Financial Reporting (KFRC).

Commercial companies that are ranked as major commercial companies based on the accounting law are obliged to submit and publish audited financial statements, while medium and small enterprises are only obliged to fill in financial statements.

The role of audited financial statements in attracting foreign investors in the private sector in Kosovo as a developing country will be analyzed in this paper. It should be noted that in the developing world audited financial statements are very important in creating confidence of potential investors, encouraging them to invest in the equity of private companies, or to invest in the form of a grant, loan or consulting.

We focused on the analysis of the case: whether this positive correlation exists in the area of foreign investment in the private sector in Kosovo. There have been many attempts to define the quality of auditing in the past; it has resulted in a definition which is widely known and generally recognized. Audit quality is the matter that is subject to direct and indirect impact.

The paper is divided into seven parts, the introduction is followed by literature review, where opinions regarding the importance of audit to investors, the quality of audit, the auditor's report, the reputation of the auditor and relevance of the findings are presented.

In the third section, some concepts about the importance of auditing and foreign investment in Kosovo are presented. The research methodology is presented in the fourth section and the last section is dedicated to the testing of hypotheses and summary of the research results.

\section{LITERATURE REVIEW}

External audit involves the engagement of an independent audit firm which through its auditors makes detailed control over the financial reports prepared by different companies. and made the verification of internal control (Comptroller's Handbook, 2003). 
According to (AU-C Section 200, 2012), the essence of external audit is that the auditors inform external users about the manner of presentation of financial statements presenting their opinion, with regard to the materialistic aspect as well as enforcement of regulations on financial reporting.

This process is necessary because the company management itself is responsible for preparing the financial statements. Therefore, the auditor appears as a third party, confirming their accuracy. External audit process is carried out in five steps (Larcker \& Tayan, 2011).

- The first step has to do with the preparation for the audit when the assessment of the areas that require special attention is done;

- The second step is concerned with reviewing, evaluating and detecting irregularities;

- The third step has to do with the evaluation of potential opportunities of fraud;

- The fourth step - assessment of internal control by focusing on weaknesses;

- The fifth step deals with the auditor's findings and opinion, which are included in the auditor report.

Based on the above-mentioned sources, it may be stated that investors are potential users of financial statements. Investors rely on auditors' report regarding financial statements to gain confidence in the data submitted by different companies. Investors also want auditor report to present three issues, such as: (PWC, 2011)

- The risk of material misstatement;

- The application of accounting standards;

- Important area of debate between the Auditor, management and the Audit Committee.

In the reviewed literature, the role of the audited financial statements and importance of audit in decision-making are consistently emphasized. External parties that are interested in the audited financial statements from the private sector are customers, suppliers, investors, banks, analysts etc. Many researchers have addressed this issue and have presented their opinions that there are multiple financial benefits from audited financial statements. External audit affects the increase of the financial statements' reliability to external investors and at the same time reduces the risk of financial investment (Fallatah, 2008).

The monitoring of an entity by auditors encourages the management to engage in internal monitoring thus improving the internal controlling system (Ghosh, 2007). The audit provides reliability for financial statements by reducing uncertainty and risk (Broadley, 2006).

Lending institutions consider the information received from the auditor as relevant and useful for decision-making in investments and lending (Duréndez Gómez-Guillamón, 2003).

Investors and businesses in general need reliable financial information and in this context the auditor plays a key role in protecting the public interest and potential investors (Elorrieta, 2002). 
From the perspective of investors or lenders, the key elements they are interested in are audit report, auditor's reputation and relevance of the auditor's findings (IFAC, 2014).

The importance of the audit of financial statements is undisputed for foreign investors, regardless of the country in which they invest. Given the fact that this paper focuses on the role of the audited financial statements from the perspective of a foreign investor in the private sector in Kosovo, we have analyzed the factors which make the audit more or less important to investors, such as auditor's report, auditor's reputation and relevance of the auditor's findings.

In a research study where auditor's opinion is studied as intermediate information, between the company and external users of the auditor's report (Salehi, 2010). The results of this study show that the auditor report serves as a basis in making investment decisions (Salehi, 2010).

According to the survey (Institute of Chartered Accountants in Australia, 2008), in the report the auditor expresses his/her opinion whether the financial statements present fairly the financial position of the company. According to the report, the auditor increases the reliability of financial statements and makes users of financial statements (e.g. investors) use them with greater confidence.

The auditor may give an unqualified opinion when he believes there is no a reason for concern and may also give a qualified opinion when expressing reservations in the disclosure of financial statements

The auditor may give an unqualified opinion when he believes there is no cause for concern and may also give a qualified opinion when the disclosure of financial statements is not made according to international standards (Asare, S. K., \& Wright, A. 2012).

The auditor's report is a very important means of communication between the auditor and the users of financial statements (Moradi et al., 2011). This source has researched the relationship between the auditor's opinion, the price of the stocks and the value of return in the country of Iran. According to the research results of the auditor, the auditor's opinion does not have a significant influence on the stock price and return value, but it is very important for parties who wish to invest in the company.

The auditor's reputation is the key element determining the importance of audit for investors; it is the basic factor that has an impact on audit quality. The auditor's reputation is built with great difficulty, and it assures customers receive stable and high-quality services. If the auditor has a good reputation, the investor has the greatest assurance on decision making (Khaddash, Nawas, \& Ramadan, 2013).

Reputable auditing companies are afraid of losing reputation and sometimes do not report on the real situation in the audited companies (McLennan \& Park, 2004).

In the last decade many companies were opened, which established many branches in all cities around the world. Considering their number there has been a division that is often referred to as Big 5 , Big 4 or Big 8, depending on the industry they operate. These companies have an almost unique reputation in the respective industry (McLennan \& Park, 2004). 
Since investors are not able to observe directly the quality of the audit and determine whether the information reported is an indication of impartial financial performance of firms, the reputation of the auditor serves as an important support for the quality and accuracy of the customer's financial statements (Khaddash, Nawas and Ramadan, cited in DeAngelo, 1981).

The audit data is all the information used by the auditor to reach conclusions on which the auditor's opinion is based. The audit evidence is necessary to support the opinion given by the auditor..

The audit procedures to obtain audit evidence can include inspection, observation, confirmation, recalculation and analytical procedures. Correctness is the measure of the quality of audit evidence, that is, relevance and quality of important findings in order to provide support for the detection of anomalies and discrepancies in the financial statements. The relevance and reliability of the findings are influenced by the source and nature of the findings and are dependent on certain circumstances (IFAC, 2014).

The aim of financial statements audit is to submit information to the market presenting specific, relevant and reliable information, which enables prediction of cash flow and reduces uncertainty which hereby creates an easier access to financing and growth investment. (Langli \& Svatsrom, 2013).

While in other countries around the world potential investors rely on the auditor's report, in Kosovo apart from considering the role of the audit report, foreign investors were stimulated in different ways. According to the survey (Shaipi, Krasniqi, Mati, \& Gashi, 2014) the authors have proved that foreign investors were stimulated by the Government of Kosovo through financial and non-financial means, such as exemption from customs duty $(26 \%)$, deferral of VAT payment $(15 \%)$, depreciation accelerated machinery $(16 \%)$, exemptions from regulatory taxes and licensing $(83 \%)$ and the provision of physical infrastructure at an affordable cost or no cost at all (82\%). Moreover, based on this research, $72 \%$ of the current investors reported that the incentives of the Government of Kosovo were a very important factor that influenced their decisions to invest in Kosovo.

The role of audited financial statements in promoting foreign investment in Kosovo in the private sector will be analyzed in the empirical part of this paper. 


\section{OVERVIEW OF THE AUDITED FINANCIAL STATEMENTS IN KOSOVO AND ON FOREIGN INVESTMENTS}

\subsection{Audited Financial Statements of Companies in Kosovo}

The audit issue in Kosovo is regulated by law with some deficiencies, or rather not in the same way as in the developed countries. In the legal aspect, while in other countries in the region and beyond, by law are defined businesses which are obliged to audit the financial statements, in Kosovo are excluded small and medium enterprises. Low awareness of business about the benefits from submitting audited financial statements has caused the situation that only a small number of Kosovar businesses have their audit done.

The audit of large companies in Kosovo is essential to establish sound financial market, ensure trust of international investors and reliability of financial reporting and guarantee transparency.

As pointed out above, in Kosovo, according to the Law on Accounting and Finance, not all businesses are obliged to go through the audit process. Based on this law, only large companies undergo this process, while small and medium enterprises draw up only a financial report. Relying on the data from the Ministry of Finance of Kosovo, just around 270 companies in Kosovo prepare financial statements and audit those statements.

\subsection{Foreign Investment in Kosovo}

Foreign direct investments are an important source of capital influx and economic development. In 2013, Turkey was the state of origin of the bulk of foreign direct investments (FDI) in Kosovo with 82.8 million euro or $28 \%$ of the total. Other countries with significant standing in terms of foreign direct investment include Switzerland (14\%), Germany and Albania (7\%). Foreign direct investment in Kosovo by country of origin as of 31 March 2014 are shown in Table 1.

Table 1. Foreign direct investment in Kosovo by country of origin as of 31 March 2014 (million euro) (Central Bank of Kosovo, n.d.)

\begin{tabular}{|l|r|r|}
\multicolumn{1}{|c|}{ Region } & Incoming IHD & Outgoing IHD \\
\hline European Union & 962.83 & 53.81 \\
\hline Other non-European countries & 111.31 & 11.41 \\
\hline Other European countries & 534.32 & 75.40 \\
\hline Total & $2,807.80$ & 140.62 \\
\hline Non-specified & $1,199.34$ & \\
\hline
\end{tabular}

On 31 March 2014, total state of foreign direct investment was recorded at 2.8 billion euro incoming investments and 141 million euro outgoing investments.

These are total foreign investments, a part of them is also in private companies as co-investment, capital investments, loans or other forms of 
investment. In this paper, the focus is on investment in private companies, where the investment is made in the form of loans mainly or other forms of financing received from international companies (EIB, EIF, KFW, or the World Bank), but those private companies that have co-financing from foreign investors were not exempted.

By looking at the reference terms presented by investors, which should be met by companies in Kosovo to get a loan, grant, consultancy or other form of financing, it is not clearly pointed out whether it is a necessary criterion for the company to have audited financial statements, it is the case only when it comes to credit or capital investment.

The elements of the audit of the financial statements that are important to stimulate a foreign investor to invest in private companies in Kosovo will be considered in the following analysis.

\section{RESEARCH HYPOTHESES AND METHODOLOGY}

\subsection{Research Hypotheses}

Three hypotheses were set forth for this topic; they are based on the assumption of the importance of audited financial statements in promoting foreign investment in the private sector in Kosovo and they are:

H1: The importance of audited financial statements has a positive correlation with the auditor's report;

H2: The importance of audited financial statements has a positive correlation with the auditor's reputation;

H3: The relevance of the findings has a positive correlation with the importance of audited financial statements.

All three variables that increase the importance of auditing and are thought to have a positive impact on promoting foreign investments in private companies in Kosovo.

Based on the extensive research on the topic on "The importance of audit of the financial statements in promotion of foreign investments in the private sector", it can be noted that in the developed countries and most developing countries the audit of financial statements of private companies is very important for foreign investors.

To reveal the importance of auditing to private companies in Kosovo, interest was expressed in some questions that directly relate to the reason for auditing financial statements of the private companies in Kosovo, and that allows drawing some conclusions on the importance of auditing. 


\subsection{Research Methodology}

The methodology for gathering information comprised a mixture of qualitative and quantitative methods. The qualitative aspect was implemented through a review of secondary sources, various research methods, analysis of certain laws, information from different links, while the quantitative component was implemented through a structured questionnaire.

Due to the limited time, interviewers' diverse location and travel expenses, conducting direct interviews with all respondents was impossible. The survey was sent to respondents electronically and answers were received within three weeks. Given that the target groups were private companies that have audited statements and financing from investors in Kosovo, the information on these companies was found through private contacts with some people who work in auditing companies in Kosovo, social contacts were used to get information on the companies that acquired a loan, grant or capital investment from a foreign investor in Kosovo.

All data were taken online, considering the fact that the survey was not carried out face to face; the survey was resent more than three times to targeted persons. Moreover, in certain cases social network was not efficient in persuading some companies to conduct the survey and they were contacted by telephone a few times. The survey sample includes 31 private companies in Kosovo, which prepare financial statements based on IFRS, and 20 of them are funded by a foreign investor.

The questionnaire was sent electronically to 70 private companies in Kosovo. From the sent surveys 40 answers were received, out of which 31 were considered valid for analysis. The data obtained from questionnaires were processed in SPSS database.

\section{DESCRIPTIVE RESULT ANALYSIS}

\subsection{General Characteristics of Respondents}

Analyzing the data received from the respondents, it can be noticed that $19.4 \%$ of respondents or 6 have completed Bachelor level education, $77.4 \%$ or 24 - Master level education and $3.2 \%$ or 1 respondent holds a Doctoral degree. Regarding the issue of specialization in accounting or auditing, $25.8 \%$ or 8 respondents were accounting technicians, $22.6 \%$ or 7 were certified accountants, $13 \%$ or 4 were statutory auditors or certified auditors, while the rest of the respondents of 38.7 or 12 interviewees had none of the above-mentioned qualifications. Characteristics of respondents is shown in Table 2.

Table 2. Characteristics of respondents [Table made by authors]

\begin{tabular}{|l|l|r|r|}
\hline & Frequency & Frequency \% \\
\hline \multirow{2}{*}{ Education } & Bachelor & 6 & $19.4 \%$ \\
\hline Master & 24 & $77.4 \%$ \\
\hline PhD & 1 & $3.2 \%$ \\
\hline Total & 31 & $100.0 \%$ \\
\hline
\end{tabular}




\begin{tabular}{|l|l|r|r|}
\hline Specialization & Accounting Technician & 8 & $25.8 \%$ \\
\hline Certified Accountant & 7 & $22.6 \%$ \\
\hline Certified Auditor & 2 & $6.5 \%$ \\
\hline Statutory Auditor & 2 & $6.5 \%$ \\
\hline None & 12 & $38.7 \%$ \\
\hline Total & 31 & $100.0 \%$ \\
\hline
\end{tabular}

Source: calculated by the authors

Referring to the survey results, in Table 3 it can be seen that the surveyed companies work in the following sectors: $3.2 \%$ - the textile sector, $9.7 \%$ metallurgy sector, $3.2 \%$ - wood sector, $41.9 \%$ - food sector and $41.9 \%$ - other sectors.

Referring to the data on the surveyed companies, the results show that $54.8 \%$ of these companies are shareholder companies with local shareholders, $16.1 \%$ with international shareholders, $19.4 \%$ - local and international shareholders and $9.7 \%$ of these companies operate in some other legal form in Kosovo.

Regarding the size of these companies based on the number of employees, $74.2 \%$ or 23 companies have more than 50 workers and $25.8 \%$ or 8 have up to 50 employees.

Considering the characteristics on the audited financial statements of these companies and their access to foreign investment it can be seen that $90.3 \%$ or 28 companies compile financial statements and report on the basis of international standards for reporting and financing (IFRS) and $93.5 \%$ or 29 companies draw up regular audited financial statements. General characteristics of enterprises are shown in Table 3.

Table 3. General characteristics of enterprises

[Table and calculations made by authors]

\begin{tabular}{|c|c|c|c|}
\hline \multicolumn{2}{|l|}{ Variables } & \multirow{2}{*}{$\begin{array}{l}\text { Frequency } \\
\\
\end{array}$} & \multirow{2}{*}{$\begin{array}{r}\text { Frequency } \% \\
3.2\end{array}$} \\
\hline Company operations & Textile & & \\
\hline & Metallurgy & 3 & 9.7 \\
\hline & Wood & 1 & 3.2 \\
\hline & Food & 13 & 41.9 \\
\hline & Other & 13 & 41.9 \\
\hline & Total & 31 & 100.0 \\
\hline \multirow{5}{*}{$\begin{array}{l}\text { Type of company by } \\
\text { ownership }\end{array}$} & Local shareholders & 17 & 54.8 \\
\hline & International shareholders & 5 & 16.1 \\
\hline & $\begin{array}{l}\text { Local and international } \\
\text { shareholders }\end{array}$ & 6 & 19.4 \\
\hline & Other & 3 & 9.7 \\
\hline & Total & 31 & 100.0 \\
\hline
\end{tabular}




\begin{tabular}{|c|c|c|c|}
\hline \multirow{3}{*}{$\begin{array}{l}\text { The average number of } \\
\text { employees in your } \\
\text { company }\end{array}$} & Up to 50 employees & 8 & 25.8 \\
\hline & Over 50 employees & 23 & 74.2 \\
\hline & Total & 31 & 100.0 \\
\hline \multirow{3}{*}{$\begin{array}{l}\text { Preparation of } \\
\text { statements according to } \\
\text { IFRS }\end{array}$} & Yes & 28 & 90.3 \\
\hline & No & 3 & 9.7 \\
\hline & Total & 31 & 100.0 \\
\hline \multirow{3}{*}{$\begin{array}{l}\text { Regular statements } \\
\text { auditing }\end{array}$} & Yes & 29 & 93.5 \\
\hline & No & 2 & 6.5 \\
\hline & Total & 31 & 100.0 \\
\hline \multirow[t]{3}{*}{ Foreign investments } & Yes & 21 & 67.7 \\
\hline & No & 10 & 32.3 \\
\hline & Total & 31 & 100.0 \\
\hline \multirow[t]{8}{*}{ Form of financing } & Grant & 4 & 12.9 \\
\hline & Loan & 2 & 6.5 \\
\hline & Financial consultancy & 3 & 9.7 \\
\hline & $\begin{array}{l}\text { Capital investment in the } \\
\text { company }\end{array}$ & 11 & 35.5 \\
\hline & Other & 1 & 3.2 \\
\hline & Total & 21 & 67.7 \\
\hline & No foreign founding & 10 & 3.3 \\
\hline & Total & 31 & 100.0 \\
\hline
\end{tabular}

As regards their access to funding, these companies show that $67.7 \%$ of companies or 21 of them are funded by foreign investors, while 10 are not funded. Forms of foreign financing these companies receive are according to this distribution: $12.9 \%$ in the form of a grant, $6.5 \%$ in the form of loans, $9.7 \%$ in the form of financial consulting $35.5 \%$ in the form of capital investment and $3.2 \%$ in other form.

\subsection{The Importance of Audited Financial Statements}

To characterize the importance of audit of financial statements of private companies in Kosovo, five questions were formulated regarding the reasons why these companies opt for using audited financial statements. (Factors determining importance of the audited financial statements are shown in Table 4 (Level rating from $1-5,5$ - strongly agree and 1 - strongly disagree). 
Table. 4. Factors determining importance of the audited financial statements

[Table and calculations made by authors]

\begin{tabular}{|c|c|c|c|c|c|c|c|}
\hline Responses & No & 5 & 4 & 3 & 2 & $\begin{array}{l}\text { Expressed } \\
\text { in average }\end{array}$ & $\begin{array}{l}\text { Standard } \\
\text { deviation }\end{array}$ \\
\hline $\begin{array}{l}\text { 13. AFS is important to get loans } \\
\text { from banks in Kosovo. }\end{array}$ & 31 & $16 \%$ & $52 \%$ & $29 \%$ & $3 \%$ & 3.77 & 0.844 \\
\hline $\begin{array}{l}\text { 14. AFS is important to provide } \\
\text { reliable information to potential } \\
\text { foreign investors that may affect } \\
\text { profitability or non-profitability } \\
\text { of investment from them. }\end{array}$ & 31 & $48 \%$ & $52 \%$ & & & 4.483 & 0.508 \\
\hline $\begin{array}{l}\text { 15. AFS is important to provide } \\
\text { reliable information on the } \\
\text { performance of the company to } \\
\text { shareholders. }\end{array}$ & 31 & $48 \%$ & $45 \%$ & $7 \%$ & & 4.419 & 0.620 \\
\hline $\begin{array}{l}\text { 16. AFS is important in fulfilling } \\
\text { the obligations and duties arising } \\
\text { from law in effect on the } \\
\text { reporting and auditing of financial } \\
\text { statements (Law No. } 04 \text { / L- } 014 \\
\text { on Accounting, Financial } \\
\text { Reporting and Auditing). }\end{array}$ & 31 & $39 \%$ & $58 \%$ & $3 \%$ & & 4.354 & 0.550 \\
\hline $\begin{array}{l}\text { 17. AFS based on international } \\
\text { auditing standards (ISA) is } \\
\text { important for the Company to be } \\
\text { compared to all companies } \\
\text { (national or international) to } \\
\text { prepare financial statements } \\
\text { according to international } \\
\text { financial reporting standards } \\
\text { (IFRS). }\end{array}$ & 31 & $23 \%$ & $71 \%$ & $7 \%$ & $3 \%$ & 4.161 & 0.522 \\
\hline Total & & & & & & 4.238 & 0.609 \\
\hline
\end{tabular}

Considering the respondents' answers it can be seen that in the majority of cases respondents agreed that auditing is important to get loans from the bank, to provide reliable information to investors about the company's shareholders, to carry out the obligations arising from law and to be compared with other companies. Overall, these responses are 4.24 with a standard deviation of 0.6 indicating that the audit of financial statements in private companies in Kosovo is necessary in order to generate reliable information to third parties.

\subsection{The Importance of the Auditor's Report}

The importance of the auditor's report was determined considering the factors presented in the table below. From the responses presented in Table 5 it can be seen that respondents assessed the following factors as significant: the auditor's opinion for foreign investors, investor preference to invest in companies where the auditor's report was unqualified, the pressure of investors on companies to address the problems, which led to compiling a qualified audit's report. Factors 
determining importance of the audit's report are shown in Table 5. The overall response from respondents for all the factors shown is 3.99, with a standard deviation of 0.87 . (Level rating from $1-5,5-$ strongly agree and 1 - strongly disagree).

Table 5. Factors determining importance of the audit's report [Table and calculations made by authors]

\begin{tabular}{|c|c|c|c|c|c|c|c|}
\hline Responses & No & 5 & 4 & 3 & 2 & $\begin{array}{l}\text { Expressed } \\
\text { in average }\end{array}$ & $\begin{array}{l}\text { Standard } \\
\text { deviation }\end{array}$ \\
\hline $\begin{array}{l}\text { 18. The independent auditor's } \\
\text { opinion is important for foreign } \\
\text { investors: }\end{array}$ & 31 & $19 \%$ & $26 \%$ & $55 \%$ & & 4.35 & 0.797 \\
\hline $\begin{array}{l}\text { 19. Investors prefer to invest in the } \\
\text { companies, which received } \\
\text { unqualified auditor's opinion: }\end{array}$ & 31 & $26 \%$ & $16 \%$ & $13 \%$ & $45 \%$ & 3.193 & 1.327 \\
\hline $\begin{array}{l}20 \text { Investors press for the company } \\
\text { to take the necessary measures for } \\
\text { finding of inrregularities from the } \\
\text { auditor in order to not be repeated in } \\
\text { the future: }\end{array}$ & 31 & $19 \%$ & $36 \%$ & $39 \%$ & $65 \%$ & 3.674 & 0.871 \\
\hline $\begin{array}{l}21 . \text { It is important that the auditor } \\
\text { expresses an opinion that the } \\
\text { statements have been prepared in } \\
\text { accordance with the standards of the } \\
\text { reporting framework: }\end{array}$ & 31 & $48 \%$ & $52 \%$ & & & 4.483 & 0.508 \\
\hline $\begin{array}{l}\text { 22. It is important that the financial } \\
\text { statements comply with regulatory } \\
\text { requirements and tax institutions in } \\
\text { Kosovo: }\end{array}$ & 31 & $42 \%$ & $52 \%$ & & $6 \%$ & 4.258 & 0.893 \\
\hline Total & & & & & & 3.99 & 0.87 \\
\hline
\end{tabular}

The respondents assessed as very important the auditor's opinion regarding the preparation of financial statements in accordance with standards of the reporting framework and legislation in force.

\subsection{The Importance of Auditor's Reputation}

The importance of the auditor's reputation was addressed in five questions that considered the determining factors, which respondents rated as important.

From Table 6 it can be seen that the majority of respondents assessed the following factors as important: credibility of the auditor, the auditor's experience in the industry where the company operates, the prestige of the auditing company in the international market and the importance of the company being in the top 4 of the largest international companies.

Determinants of auditor's reputation are sown in Table 6 (Level rating from $1-5,5$ - strongly agree and 1 - strongly disagree). 
Table 6. Determinants of auditor's reputation

[Table and calculations made by authors]

\begin{tabular}{|c|c|c|c|c|c|c|c|}
\hline Response & No & 5 & 4 & 3 & 2 & $\begin{array}{l}\text { Expressed } \\
\text { in average }\end{array}$ & $\begin{array}{l}\text { Standard } \\
\text { deviation }\end{array}$ \\
\hline $\begin{array}{l}\text { 23. International audit } \\
\text { companies are more reliable } \\
\text { than local audit companies: }\end{array}$ & 31 & $41.9 \%$ & $19.4 \%$ & $19.4 \%$ & $19.4 \%$ & 3.833 & 1.185 \\
\hline $\begin{array}{l}24 \text {. It is important for the } \\
\text { audit company to have } \\
\text { experience in auditing: }\end{array}$ & 31 & $32.3 \%$ & $51.6 \%$ & $16.1 \%$ & & 4.161 & 0.687 \\
\hline $\begin{array}{l}25 \text {.It is important for the } \\
\text { audit company to have long } \\
\text { experience in the industry in } \\
\text { which your company } \\
\text { operates: }\end{array}$ & 31 & $16.1 \%$ & $41.9 \%$ & $41.9 \%$ & & 3.741 & 0.728 \\
\hline $\begin{array}{l}\text { 26. It is important for the } \\
\text { audit company is to be } \\
\text { recognized in the } \\
\text { international market: }\end{array}$ & 31 & $25.8 \%$ & $48.4 \%$ & $22.6 \%$ & $3.2 \%$ & 3.967 & 0.795 \\
\hline $\begin{array}{l}\text { 27. Auditing by international } \\
\text { companies that operate in } \\
\text { Kosovo and which are in the } \\
\text { top } 4 \text { of large international } \\
\text { audit companies (Delloite, } \\
\text { KPMG, PWC and E \& Y) is } \\
\text { very important: }\end{array}$ & 31 & $32.3 \%$ & $25.8 \%$ & $25.8 \%$ & $16.1 \%$ & 3.741 & 1.094 \\
\hline Total & & & & & & 3.88 & 0.898 \\
\hline
\end{tabular}

The overall response regarding these factors is $3.88 \%$ with a standard deviation of $0.89 \%$. Analyzing self-evaluation given in the responses to the questions, it can be determined which factor is considered to be of the greatest importance

\subsection{The Relevance of the Findings}

The relevance of the findings as a factor that affects the importance of audited financial statements was addressed in five questions shown in Table 7. Respondents assessed the following factors as important: fulfilment of recommendations and further improvement by the management of the company and importance of these improvements for investors in the following periods, paper-management of audit findings.

Furthermore, Table 7 shows the degree of importance ascribed to providing sufficient evidence from the auditor on the findings and the risk of any finding. The average of the responses from respondents is 04.29 with a standard deviation 0.60 . (Level rating from $1-5,5-$ strongly agree and 1 - strongly disagree). 
Table 7. Determinants of the relevance of the findings

[Table and calculations made by authors]

\begin{tabular}{|c|c|c|c|c|c|c|c|}
\hline Response & No & 5 & 4 & 3 & 2 & $\begin{array}{l}\text { Expressed } \\
\text { in average }\end{array}$ & $\begin{array}{l}\text { Standard } \\
\text { deviation }\end{array}$ \\
\hline $\begin{array}{l}\text { 28. It is important for the } \\
\text { company's management to } \\
\text { meet the recommendations and } \\
\text { improve in the following } \\
\text { periods: }\end{array}$ & 31 & $48.4 \%$ & $48.5 \%$ & $3.2 \%$ & & 4.451 & 0.567 \\
\hline $\begin{array}{l}29 . \text { Foreign investors also } \\
\text { require a letter from the } \\
\text { management that includes } \\
\text { findings and recommendations } \\
\text { made by the external auditor: }\end{array}$ & 31 & $22.6 \%$ & $74.2 \%$ & $3.2 \%$ & & 4.193 & 0.477 \\
\hline $\begin{array}{l}\text { 30. It is important for external } \\
\text { investors that the given } \\
\text { recommendations are } \\
\text { implemented in the following } \\
\text { periods: }\end{array}$ & 31 & $29.0 \%$ & $67.7 \%$ & $3.2 \%$ & & 4.258 & 0.514 \\
\hline $\begin{array}{l}\text { 31. It is important for the } \\
\text { auditor to provide sufficient } \\
\text { evidence on the presented } \\
\text { findings: }\end{array}$ & 31 & $51.6 \%$ & $48.4 \%$ & & & 4.516 & 0.508 \\
\hline $\begin{array}{l}\text { 32. It is necessary to present the } \\
\text { risk of any finding made by the } \\
\text { external auditor: }\end{array}$ & 31 & $32.3 \%$ & $48.4 \%$ & $12.9 \%$ & $6.4 \%$ & 4.032 & 0.948 \\
\hline Total & & & & & & 4.290 & 0.603 \\
\hline
\end{tabular}

Referring responses, which are agree and strongly agree (an average of over 4), it can be considered that the respondents have estimated that three independent factors of this paper stated that the audit of financial statements is very important.

\section{TESTING THE HYPOTHESES}

Correlation was used in testing the hypotheses, which tested whether there is a link between the independent variables separately with the dependent variable, which is the importance of the audit. The outcome shows that the coefficient Sig 0.032 is smaller than 0.05 which indicates that there is a significant correlation between importance of audited financial statements and auditor's report.

Considering these results, the Pearson correlation coefficient of 0.386 proves that the relation between them is positive and the bonding strength is average. Based on these results, it can be concluded that the first hypothesis have been fully completely proved. $\mathrm{H} 1$ : The importance of audited financial statements has a positive correlation with the auditor's report. 
Table 8. The relationship between the importance of the auditing and the auditor's report [Table and calculations made by authors]

\begin{tabular}{|l|l|l|l|}
\hline \multicolumn{2}{|l|}{ Correlations } & $\begin{array}{l}\text { Importance } \\
\text { of auditing }\end{array}$ & Auditor's report \\
\hline \multirow{2}{|l|}{} & Pearson Correlation & 1 & $0.386^{*}$ \\
\cline { 2 - 4 } & Sig. (2-tailed) & & 0.032 \\
\hline No & 31 & 31 \\
\hline
\end{tabular}

The report of audit significance and auditor's reputation shows that these two variables have a link between themselves since the coefficient of significance $p=0.025$ is less than 0.05 .

The outcome of the Pearson correlation coefficient is 0.401 , and that indicates that the relationship between these variables is positive and the correlation strength is average. Based on these results, we can also conclude that the second hypothesis has been confirmed. H2: The importance of audited financial statements has a positive correlation with the auditor's reputation.

Table 9. The relationship between the importance of the auditing and auditor's reputation [Table and calculations made by authors]

\begin{tabular}{|l|l|l|l|}
\hline \multicolumn{2}{|l|}{ Correlations } & $\begin{array}{l}\text { Importance } \\
\text { of audit }\end{array}$ & $\begin{array}{l}\text { The auditor's } \\
\text { reputation }\end{array}$ \\
\hline & Pearson Correlation & 1 & $0.401^{*}$ \\
\cline { 2 - 4 } & Sig. (2-tailed) & & 0.025 \\
\hline No & 31 & 31 \\
\hline
\end{tabular}

Source: calculated by the authors

From the result of the importance of audit and from the relevance of findings by the auditor, it can be seen that the coefficient Sig 0.036 is less than 0.05 , which indicates that there is a significant correlation between the relevance of the findings and the importance of audited financial statements. From the coefficient result of the Pearson correlation of 0.377 , it is understood that the relationship between these variables is positive and the correlation strength is below average. Based on these results, it can be concluded that the third hypothesis has been confirmed. H3: The relevance of the findings has a positive correlation with the importance of audited financial statements 
Table 10. The relationship between the importance of the audit findings and its relevance [Table and calculations made by authors]

\begin{tabular}{|l|l|l|l|}
\hline \multicolumn{2}{|l|}{ Correlations } & Importance & Relevance \\
\hline \multirow{3}{*}{ Importance } & Pearson Correlation & 1 & $0.377^{*}$ \\
\cline { 2 - 4 } & Sig. (2-tailed) & & 0.036 \\
\cline { 2 - 4 } & No & 31 & 31 \\
\hline
\end{tabular}

After the conducted analysis, authors summarize the conclusions.

\section{CONCLUSION}

One of the purposes of applying international standards for reporting and funding is to prepare similar, credible and transparent statements, which help increase capital turnover and trade worldwide. Investors are interested in the markets they understand and trust. Based on the international standards for reporting and financing audited financial statements ensure data reliability for foreign investors.

From the results of the paper it can be stated that audited financial statements are very important for private companies in Kosovo, so that they have an easier access to bank loans, can provide reliable information to different contractors, provide reliable information to potential investors, be comparable with the companies which belong to the same industry.

By testing the hypotheses, in the course of analysis it has been proved that there is a significant positive relationship between the importance of audited financial statement with the auditor's report, the auditor's reputation and relevance of the findings. All these variables we have considered positively impact on the auditing of the financial statements, as an element for promotion of foreign investments in private companies in Kosovo.

Based on the results of this research it is recommended that in order to encourage foreign investors private companies should:

- Compile financial statements and their reports on the basis of international reporting standards and funding (SRFN) in order to create uniformity and be comparable with other companies;

- Private companies in Kosovo need to raise awareness and publish audited financial statements more regularly taking into consideration the benefits that can help in avoiding problems, as well as easing the access to foreign investment and other financing;

- Private companies in Kosovo should focus on the quality of financial reporting, as this affects the opinion of the auditor on the credibility of their financial statements.

The paper concludes with the following statement:

"If we want to attract foreign investors, if we want to ensure credibility of enterprises operating in Kosovo, auditing should be employed as one of the 
principal means in regulating financial reporting. Foreign investors still do not have full confidence that in Kosovo financial statements prepared by private companies actually represent their real financial standing."

\section{REFERENCES}

Asare, S. K., \& Wright, A. (2012). Investors', Auditors', and Lenders' Understanding of the Message. Accounting Horizons, 26(2), 193-217. https://doi.org/10.2308/acch-50138

AU-C Section 200. (2012). Overall Objectives of the Independent Auditor and the Conduct of an Audit in Accordance With Generally Accepted Auditing Standards. Retrieved November 07, 2014, from http://www.aicpa.org/research/standards/auditattest/downloadabledocuments/au-c00200.pdf

Arruñada, B. (2010). Mandatory accounting disclosure by small private companies. European Journal of Law and Economics, 32(3), 377-413. https://doi.org/10.1007/s10657-010-9145-3

Broadley, D. (2006). Auditing and its role in Corporate governance, FSI Seminar on Corporate Governance for Banks.

Berry, A., \& Robertson, J. (2006). Overseas bankers in the UK and their use of information for making lending decisions: Changes from 1985. The British Accounting Review, 38(2), 175191. https://doi.org/10.1016/j.bar.2005.10.004

Central Bank of the Republic of Kosovo. (n.d.). Retrieved from http://www.bqk-kos.org/

Comptroller's Handbook. (2003). Internal and External Audits. Comptroller of the Currency Administrator of National Banks.

Duréndez Gómez-Guillamón, A. (2003). The usefulness of the audit report in investment and financing decisions. Managerial Auditing Journal, 18(6/7), 549-559. https://doi.org/10.1108/02686900310482687

Elorrieta, A. M. (2002). Disclosure and Transparency Accounting and Auditing, The Third Meeting of the Latin American Corporate Governance Roundtable, OECD \& World Bank Group.

Fallatah, Y. (2008). The role of asset reliability and auditor quality in equity valuation, 8th Global Conference on Business \& Economics, Florence, Italy.

Ghosh, S. (2007). External Auditing, Managerial Monitoring and Firm Valuation: An Empirical Analysis for India. International Journal of Auditing, 11(1), 1-15. https://doi.org/10.1111/j.1099-1123.2007.00353.x

IFAC. (2014). Handbook of International Quality Control, Auditing, Review, Other Assurance, and Related Services Pronouncements. Volume I.

Institute of Chartered Accountants in Australia. (2008). The role and function of external auditors. Chartered Accountants Auditing \& Assurance Handbook, Australia, pp. 1-8.

Khaddash, A. H., Nawas, A. R., \& Ramadan, A. (2013). Factors affecting the quality of Auditing: The Case of Jordanian Commercial Banks. International Journal of Business and Social Science, 4(11), 206-222. Retrieved October 26, 2014, from http://www.ijbssnet.com/journals/Vol_4_No_11_September_2013/20.pdf

Langli, Ch. J., \& Svanstöm, T. (2013). Audits of private firms. Norwegian Bussines SchoolWorking paper, January 2013.

Larcker, F. D., \& Tayan, B. (2011). Financial Reporting and External Audit. Retrieved November 07, 2014, from https://www.gsb.stanford.edu/sites/gsb/files/publication-pdf/cgri-quick-guide10-financial-reporting-external-audit.pdf

McLennan, A., \& Park, I.-U. (2004). The Market for Liars: Reputation and Auditor Honesty, p. 27.

Moradi, M., Salehi, M., Rigi, M., \& Moeinizade, M. (2011). The effect of qualified audit report on share prices and returns: Evidence of Iran. African Journal of Business Management, 5(8), pp. 3354-3360.

PWC. (2011). Investor view. Insight from the investment community. Retrieved November 08, 2014, from http://www.pwc.com/en_GX/gx/audit-services/corporate-reporting/publications/ investor-view/pdf/pwc-changes-investors-would-like-to-see-in-an-audit.pdf 
Salehi, M. (2010). Evaluating Effectiveness of External Auditors' Report: Empirical Evidence from Iran. Pakistan journal of commerce and social sciences, 4(1), 69-83. Retrieved October 26, 2014, from http://www.jespk.net/publications/30.pdf

Shaipi, K., Krasniqi, B., Mati, B., \& Gashi, E. (2014). Investors' Perceptions of Kosovo's Business Environment. Survey with Current and Potential Investors, pp. 1-53.

\section{AUTHORS`SHORT BIOGRAPHIES}

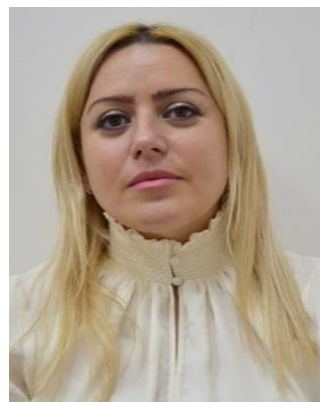

Leonora Haliti Rudhani was born in Gjilan, Kosovo on 28.09.1984. She received a Bachelor degree in economics from the University of Prishtina, the Faculty of Economics, in 2006 and a Master degree in economics from University of Prishtina, the Faculty of Economics, in 2012. She is a $\mathrm{PhD}$ student in PhD degree at the University of Prishtina, the Faculty of Economics, in the field of Banking, Finance and Accounting.

Lecturer at the University of Applied Sciences, Ferizaj, 2017 - present

Teaching Assistant at the University of Applied Sciences, Ferizaj, 20152017;

Teaching Assistant, the University of Prishtina, Faculty of Applied Sciences in Ferizaj, 2013-2015;

Senior official of finance - the University of Prishtina, Faculty of Philology, 2009-2013;

Officer of payroll - the University of Prishtina, Rectorate, 2007-2009.

E-mail: leonora_rudhani@hotmail.com

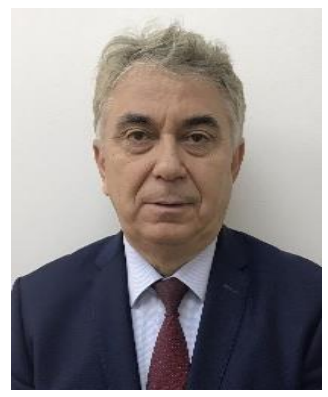

Hysen Ismajli was born in Kamenice on 20 June of 1959. He received a Bachelor degree in economics from the University of Prishtina, the Faculty of Economics, in 1982 and a Master degree in economics from the University of Zagreb, the Faculty of Economics, in 1986. He received a $\mathrm{PhD}$ degree from the University of Prishtina, the Faculty of Economics, in 2001 in the field of Banking, Finance and Accounting.

Professor, course "Economics", High School of Economics, Kamenicë, 1982-1984;

Teaching Assistant, course "Business Theory and Analysis", University of Prishtina, Faculty of Economics, 1984-1991;

Lecturer, course "Planning and Business Policy of an Enterprise" and "Financial Markets and Stock Exchange", University of Prishtina, Faculty of Economics, 1991-2002;

Assistant Professor, course "Control, Audit and Financial Analysis", University of Prishtina, Faculty of Economics, 2002-2006;

Lecturer, course "Financial Market and Stock Exchange", University of Tetovo, Faculty of Economics, 1994-2005;

Assistant Professor, course "Audit and Analysis of Financial Statements", University of Prishtina, Faculty of Economics, 2002-2012;

Assistant Professor, course "Audit and Financial Analysis", University of Prishtina, Faculty of Economics, 2007-2012;

Professor, course "Audit 2" and "Financial Analysis 2", Master program, University of Prishtina, Faculty of Economics, 2005 - present;

Professor, PhD program in Banking Finance and Accounting, University of Prishtina, Faculty of Economics, 2013 - present. 


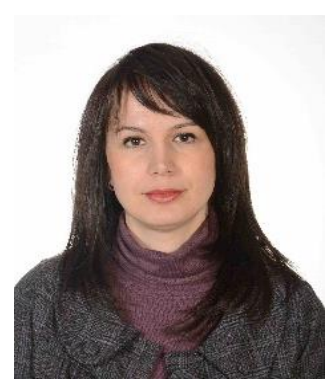

Albulena Mustafa was born on 18.09.1983. She received a Bachelor degree in Management and Informatics from the University of Prishtina, the Faculty of Economics, in 2005 and a Master degree in Management from the University of Prishtina, the Faculty of Economics, in 2013. She is a PhD student at the University of Prishtina, the Faculty of Economics, in the field of Banking, Finance and Accounting.

Head of the Treasury Unit - ProCredit Bank Kosova, Prishtina, 2012 present;

Liquidity and Funding Coordinator - ProCredit Bank Kosova, Prishtina, 2006 - 2012;

Admin Secretary - ProCredit Bank Kosova, Prishtina, February -November 2006;

Actuary Assistant - ProCredit Bank Kosova, Prishtina, November 2005 - February 2006.

E-mail: malbulena@hotmail.com 